\title{
English language learning difficulties in Saudi Arabia: Tabuk University as a case study
}

\author{
Dr. Nadyh Naser R Alawfi
}

Assistant Professor at the Department of Languages and

Translation, Faculty of Education and Arts, University of Tabuk, Saudi Arabia.

\begin{abstract}
English has undoubtedly become the world's most influential international language. Researchers are interested in the teaching of English for a variety of sociolinguistic and pedagogical reasons, most notably the development of higher education in the teaching of English as a Foreign Language. Numerous initiatives have been launched to promote the teaching and learning of English as a foreign language in non-English speaking countries, including the Arab world. More precisely, in Saudi Arabia, critical knowledge of teaching and learning English is considered critical in education in order to improve students' proficiency in the English language, particularly in speaking. The present article focuses on the specific English language learning barriers associated with speaking, using Tabuk University as a case study. Ten English-speaking classes at Tabuk University were observed during the foundation year in order to ascertain the reasons for Saudi students' lack of communication. The English program and curriculum, instructional strategies, and students' motivation, anxiety, and reluctance will all be discussed in detail as the primary factors affecting speaking proficiency and language learning. As a result, it is critical to research the aforementioned factors in order to increase awareness of some of the potential English learning barriers faced by Saudi students. This will contribute to the overall academic English language standard at Tabuk University, particularly in terms of speaking proficiency.
\end{abstract}

Keywords:

Anxiety and reticence, Curriculum, Saudi Arabia, Speaking barriers, Students' motivation. 


\title{
صعوبات تعلم اللغة الإنجليزية في المملكة العربية السعودية: دراسة حالة جاهعة تبوك
}

\author{
د. ناديه ناصر العوفي والترئي \\ أستاذ مساعد بقسم اللغات والترجمة، كلية التربية و الآداب، جامعة تبوك
}

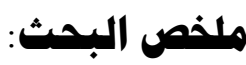

أصبحت اللغة الإنجليزية بلا شك اللغة الدولية الأكثر تأثيرًا في العالم. يهتم الباحثون

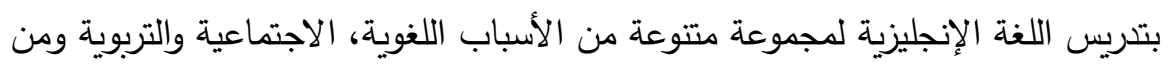

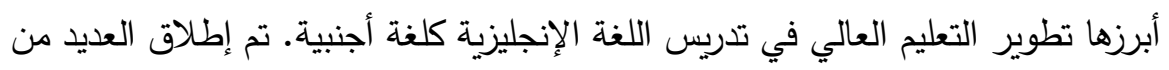
المبادرات لتعزيز تعليم وتعلم اللغة الإنجليزية كلغة أجنبية في البلدان غير الناطقة باللغنة

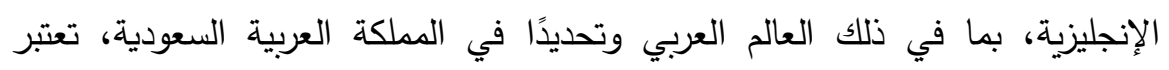

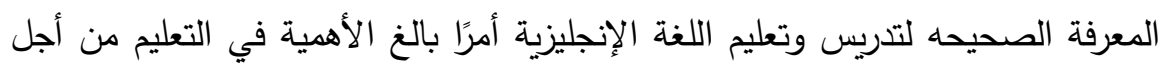

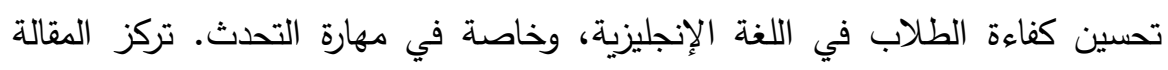
الحالية على حواجز تعلم اللغة الإنجليزية وخاصة المرتبطة بمهارة التحدث، ودراسة الحاله

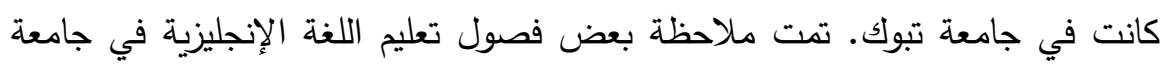

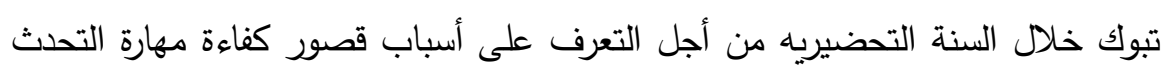

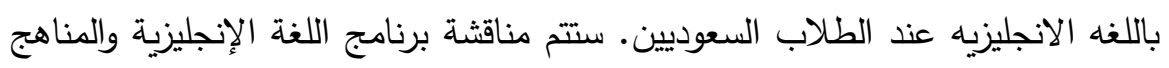
الدراسية والاستراتيجيات التعليمية ودوافع الطلاب وقلقهم بالتفصيل كعوامل أساسية تؤثر

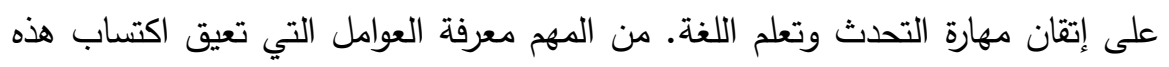

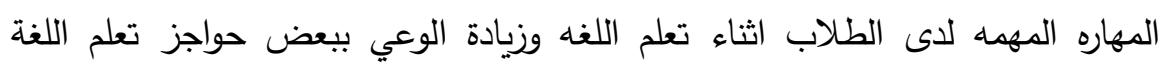

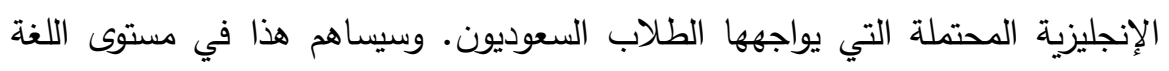

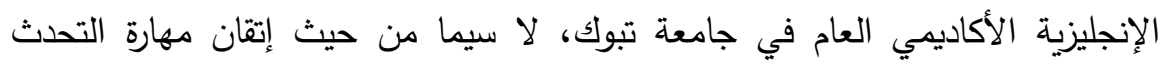

بمهاره. كلمات مفتاحية: القلق- التحفظ- المناهج الدراسيه- المملكه العربيه السعوديه- الحواجز

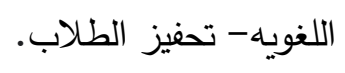




\section{English language learning difficulties in Saudi Arabia: Tabuk University as a case study}

Dr. Nadyh Naser R Alawfi

مجلة وادي النيل للاراسات والبحوث الإنسانية والاجتماعية والتريوية (مجلة علمية محكمة)

\section{Introduction}

Numerous researchers and scholars are interested in the teaching of English in the Gulf region in general, and Saudi Arabia in particular, particularly in terms of programs, curricula, teaching strategies, and students' attitudes toward university learning. According to Ahmad Al-Khotaba at el. (2020), English instruction at Saudi universities serves two purposes: first, it strengthens students' foundations in English; and second, it lays the groundwork for a more focused approach to specific aspects of English language learning that will be used in the coming years as they pursue their specialties after meeting the entry requirements for their chosen departments. Although English is taught in Saudi Arabian schools as a compulsory foreign language, critical aspects of the curriculum receive insufficient attention. "Saudi Arabia's Kingdom has advanced significantly in terms of political, social, and economic development. Since 1925, the Ministry of Education has required schools to teach English as a foreign language (EFL) " (Al Haq, 2020). According to Saudi Arabia's educational policy, the purpose of teaching English is to provide students with knowledge of at least one international language, and the only one available for learning and teaching as an official foreign language is English. Alsuelmi (2021) believes that by learning English, students will be able to communicate with and represent their culture to the rest of the world. Additionally, there has been an increase in interest in learning English as a foreign language in the Arab world as a result of the numerous opportunities it provides its speakers in a variety of fields. However, one must bear in mind the difficult and frequently complicated process of learning and teaching English in Saudi Arabia; more precisely, the process of learning and teaching speaking skills at the various levels of the Saudi educational system, which encompasses elementary, intermediate, secondary, and university levels. Among the other 


\section{مجلة وادي النيل للاراسات و البحوث الإنسانية والاجتماعية والتربوية (مجلة علمية محكمة)}

(ISSN : 2536 - 9555)

English language skills, speaking is still the most difficult to acquire efficiently. Additionally, the reasons for a student's lack of speaking ability are not always discernible. This paper will discuss some of the most significant language learning barriers that were observed during the data collection phase of this study. The educational system in Saudi Arabia, more specifically at Tabuk University, will be discussed, as well as the English language curriculum and teaching strategies. Finally, this paper will discuss students' motivation for learning English at Tabuk University, as well as their anxiety and reluctance to speak.

\section{Background}

Saudi Arabia's compulsory education system is divided into three levels: the primary level, which consists of six grades, the intermediate level, which consists of three grades, and the secondary level, which consists of three grades. Students begin learning English in the fourth year (year 4) of primary school, when they are between the ages of 9 and 11. At the primary level, there are four weekly English sessions lasting 55 minutes each. This pattern continues through the Saudi System's remaining three primary compulsory educational stages. In other words, all stages have the same number of classes and minutes. One could argue that students aged 6 to 18 do not receive enough English input due to a lack of English classes, low teacher quality, the English language curriculum, and classroom teaching strategies. These factors contribute to future language learning difficulties for students as they enter their foundation year (the first year of Saudi universities) or communicate in English. For instance, the implementation of English as a foreign language in Arab countries and the Gulf States has received significant attention as a result of increased globalisation, which has compelled all countries to adopt an international language. Thus, English has been accepted in various educational institutions throughout the Gulf States, including Kuwait and the Emirates, and nations such as these are now attempting to teach English as a mandatory subject to students beginning in kindergarten (aged four to five years old) and 


\section{English language learning difficulties in Saudi Arabia: Tabuk University as a case study}

Dr. Nadyh Naser R Alawfi

$$
\text { مجلة وادي النيل للاراسات والبحوث الإنسانية والاجتماعية والتربوية (مجلة علمية محكمة) }
$$

continuing throughout their education. Students must be prepared to study the majority of their subjects in English at the university level, which results in a more effective language learning outcome throughout the educational movement ((Troudi \& Hafidh, 2017).

Despite the Saudi government's efforts to develop a comprehensive curriculum and provide textbooks, the teaching-learning process appears futile due to a lack of actual skill development. The Saudi Ministry of Higher Education is committed to achieving excellence in effective English language teaching and learning in education; however, progress has been slow and continues to be insufficient, particularly at the college level (Alshammari, 2020). This is a frequent occurrence at nearly every stage of English learning in the Kingdom of Saudi Arabia (KSA). In other words, the lack of English language development affects all levels of education and all independent regions in Saudi Arabia where teaching English as a foreign language is mandated by the Ministry of Education.

English as a compulsory subject has garnered considerable attention from both the Ministry of Education and the Saudi community. Due to the language's importance, parents are willing to pay for additional lessons to increase their children's awareness of it. It is the language of economic contracts, higher education, international aviation research, international affairs, and international cooperation on a global scale; additionally, it is a language shared by many millions of people worldwide. Indeed, one cannot deny the significant advancements made in the field of English language education in the KSA. According to Ahmad AlKhotaba at el. (2020), over the course of several decades, the teaching and learning of English as a foreign language in the KSA has undergone numerous changes and modifications. The Saudi Teaching English as a Foreign Language (TEFL) curriculum was initially developed in 1999 by the Department of English Language within the Saudi Educational Directorate of Curriculum, with 


\section{مجلة وادي النيل للاراسات والبحوث الإنسانية والاجتماعية والتربوية (مجلة علمية محكمة)}

(ISSN : 2536 - 9555)

oversight from the Saudi Ministry of Education. According to this curriculum, the purpose of TEFL is to emphasize the four language skills (listening, speaking, reading, and writing) in order to prepare students to communicate effectively in English, the world's first spoken language. According to Dr Talal Al- Hajailan (2020), two curriculum documents were developed to specify the TEFL aims and objectives throughout the KSA's history." The first document was created in 1987 and served as the foundation for all subsequent TEFL textbooks. In 1989, a group of authors collaborated with the King Fahad University of Petroleum and Minerals in Saudi Arabia to create the new series 'English for Saudi Arabia' (KFUPM). The new textbooks incorporated the most up-to-date teaching method, dubbed 'the communicative method.' The second TEFL document was created and'modified by the Department of English in the Directorate of Curriculum under the Ministry of Education in Saudi Arabia.' " (Alshammari, 2020., p. 3).

However, the goal of teaching English in Saudi Arabia at all levels, schools, colleges, and universities, is defined in the Saudi Policy of Education and is included in each textbook, as follows: "Providing students with at least one of the living languages in addition to their native tongue, in order to enable them to acquire knowledge and sciences from other communities and to participate in the service of Islam and humanity" (Al-Hajailan, 2020).

On the basis of this objective, which has been adapted to teach English in Saudi Arabia, and in order to provide a theoretical and critical review of TEFL in Saudi Arabia, an in-depth case study of one of the Saudi universities will be presented to shed light on the educational process for teaching speaking at Tabuk University. Additionally, the root causes of the educational system's weaknesses at Tabuk University will be identified, as well as the language teaching process's weaknesses in this context. 
English language learning difficulties in Saudi Arabia: Tabuk University as a case study

Dr. Nadyh Naser R Alawfi

مجلة وادي النيل للاراسات والبحوث الإنسانية والاجتماعية و التربوية (مجلة علمية محكمة)

\section{The Tabuk University Program and curriculum}

The University of Tabuk was established in 2006 to fulfill the monarchy's objective of expanding higher education throughout the kingdom. The university today includes approximately 1659 faculty members, $40 \%$ of whom are female, and more than 36,000 students. The institution strives to be a model of educational excellence and growth. The university's main campus is located in Tabuk, a city in the Kingdom's northwest. Additionally, the purpose of teaching English was to establish programs that met worldwide quality and academic accreditation criteria and to develop curricula that adhered to a set of quality standards. Additionally, the primary purpose was to undertake research and studies on the construction of academic programs in order to provide an assessment of learning results (Administration of Tabuk, 2006). To accomplish the aforementioned TEFL objectives, Tabuk University's English teaching curriculum has undergone major revisions as a result of the language's objectives not being met in each of the previously taught textbooks. According to Alshammari (2020)., who conducted a study on the development of the EFL teaching and learning curriculum in the Saudi university and college context, an authentic EFL text should be designed and oriented around grammar and writing skills, while also including numerous practical exercises aimed at developing listening and speaking skills. Additionally, English courses in schools and universities should progressively but noticeably raise the bar for language learning in order to examine the bar.

The university's textbook has been revised multiple times. English for Saudi Arabia was released in 2001 as a mandatory textbook that reflects the Saudi national curriculum. The textbook is divided into two volumes, and students must complete both over the academic year. While each book concentrates on one or two language skills, for example, reading and writing in book one and listening and speaking in book two, not all language skills receive 
مجلة وادي النيل للاراسات والبحوث الإنسانية والاجتماعية والتريوية (مجلة علمية محكمة)

(ISSN : 2536 - 9555)

sufficient attention throughout the year, with speaking skills being the most neglected. Alqahtani comments of the university-level English language text book, "These volumes serve as a bridge between intermediate and secondary courses" (2018.P 124). Although these books covered and reflected the majority of language skills, neither teachers nor students were able to select the abilities that needed to be emphasized based on the student's needs. Each of these books contains nearly identical units. Lessons vary according to skill level; for example, some focus on listening and speaking activities, while others on grammar, reading, and vocabulary development. Finally, writing is featured in these novels, although more prominently than the other skills. According to certain reviews of these textbooks, Alshammari (2020) surmised the following: "Speaking about the situation in the Kingdom of Saudi Arabia, where there is a shortage of trained teachers and textbooks. As a result, teachers are obligated to adhere strictly to the texts. The EFSA teacher's handbook exerts control over teachers, which may result in less diversity and flexibility in the materials delivered and in teachers with minimal teaching experience. As a result, educators must review their materials. Another problem is the absence of Saudi teachers' involvement in developing and reviewing the material, as the Ministry of Higher Education in the Kingdom of Saudi Arabia is in charge. Despite the critical nature of material evaluation, there appears to be a dearth of empirical study in comparison to theoretical research "'. p.2) (Alsulami, 2021). Furthermore, as a result of the students' examination results and the insufficient outcome of learning, the Ministry of Higher Education's evaluation has failed to satisfy the learning objectives. As a result, an in-depth examination was conducted in order to update and alter these textbooks (AlHarbi, 2021).

As a result, the Ministry of Higher Education decided on a trial edition of a new course book aimed at improving language learning effectiveness. This book, titled "Challenges for Successful English Learning," was written for secondary school students in Saudi 


\section{English language learning difficulties in Saudi Arabia: Tabuk University as a case study}

Dr. Nadyh Naser R Alawfi

$$
\text { مجلة وادي النيل للاراسات والبحوث الإنسانية والاجتماعية والتربوية (مجلة علمية محكمة) }
$$

Arabia and has now been approved for use in the foundation year at Tabuk University. This textbook is a combination of two books: a "student book" that contains studies for the English class with the teacher, and a "work book" that contains activities that students can practice independently at home without the assistance of the teacher. Essentially, the Ministry has redesigned the contents of this book and placed a premium on improving students' critical thinking skills while studying English through the use of the communicative approach as an effective instrument for foreign language learning. The "Challenges English text book" is divided into four modules that emphasize two critical skills: learning grammar and applying it to everyday language use through student communication inside the language class. The book is divided into sections on "receptive skills" (hearing and reading) and "productive skills" (speaking and writing). All four modules should be completed within an academic year, with two tests sandwiched between each pair of modules. Although the teacher must still strictly adhere to the Ministry of Education's book plan, this new book contains an excellent modern approach for teaching English language. It was developed and constructed specifically for the Kingdom of Saudi Arabia in collaboration with the Ministry of Higher Education and Pearson Longman, the publisher of the English language course book (2010). The book is organized around the Communicative Language Teaching methodology, which is an outstanding method for effectively assisting learners in acquiring a foreign language. According to Alakrash, who contributed to the definition of communicative competence (or communicative competence), communicative competence is "relative and heavily dependent on the cooperation of all participants, as it is a highly dynamic concept in which at least two individuals are involved in the process of meaning negotiation" (2021, p.8). 


\section{مجلة وادي النيل للاراسات والبحوث الإنسانية والاجتماعية والتربوية (مجلة علمية محكمة)}

(ISSN : 2536 - 9555)

The book began promisingly when it was first used in both the secondary stage and the foundation year of university, with the goal of assisting students in improving their language skills. Through personal growth, the "New Challenges course books" have already aided students in becoming more successful learners and global citizens. However, despite the fact that this book was only used for two years of teaching at Tabuk University, the Ministry of Education has decided to update the course book once more. According to the ministry's final Academic year's results, the book failed to satisfy the purpose of EFL education in Saudi universities and schools.

In 2012, the new course book was renamed "Flying High for Saudi Arabia," and was written specifically for the country by the English Language Development Project, which remains under the Ministry of Education's control. The book followed a unit-based and lessonbased approach to teaching English. The book's objective was to educate readers about grammar, language functions, vocabulary, and pronunciation. Despite the variety of topics covered in this book and the emphasis on pronunciation, which is the first time in Saudi Arabia that this is taught as an individual skill, the book was only a pilot edition of the Saudi curriculum adopted at Tabuk university, and it was renamed "Cambridge Touch Stone" in 2013 to include series $1,2,3$, and 4 . While this textbook covers a variety of language skills that adhere to a high quality of language instruction, the amount of units and the language skills presented in each unit are rather demanding for both teachers and students to cover. Throughout their attendance at Tabuk university's English language classes and as part of the data collection for this research, which will be discussed in greater detail later in this paper, both teachers and students complained about the massive amount of lessons that must be covered during the entire academic year in accordance with Ministry directives to adhere to lesson and unit plans. According to (Saleh Alharbi at el., 2021), regulating the teacher's guide in accordance with Ministry regulations will invariably result in a lack of originality and flexibility in language 


\section{English language learning difficulties in Saudi Arabia: Tabuk University as a case study}

Dr. Nadyh Naser R Alawfi

$$
\text { مجلة وادي النيل للاراسات والبحوث الإنسانية والاجتماعية والتربوية (مجلة علمية محكمة) }
$$

instruction. Saleh Alharbi at el. (2021) added that there is a need to re-evaluate the learning/teaching context in public schools and universities in the Kingdom of Saudi Arabia, as well as to agree on new materials that reflect the requirements for learning English in society, while also taking into account the needs of Saudi students and teachers. The Ministry of Education and the Ministry of Higher Education agreed on the "Cambridge Touchstone" textbook as the foundation year textbook for EFL instruction in Saudi universities.

In Saudi Arabia, and particularly at Tabuk University, curriculum creation has largely ignored the aspects (such as materials, language instructor opinions, and learner needs) that should be considered during rational curriculum development. Alsulami (2021) classified sensible curriculum adjustments and evaluation into two distinct categories. The first is an impressionist overview, which "requires a cursory examination of a large amount of fresh material from which to choose." This strategy, however, cannot be followed because teachers are not permitted to alter the materials and the Ministry of Education already provides and plans the teaching materials and classes. The second method mentioned by Alshammari (2020) in evaluating textbooks is an in-depth examination of language textbooks, which requires a thorough and close examination that can be conducted by both the teacher and the Ministry of education in order to determine how certain skills and different materials fit the students' language learning needs.

Goh, C. C., \& Vandergrift (2021, p. 10) define curriculum evaluation as "principles and processes for the planning, implementation, evaluation, and management of an educational program." Additionally, the Ministry of Education and Tabuk University's administration should demonstrate an awareness of what occurs in each edition provided by the Ministry prior to adapting new English textbooks for University instruction. The 


\section{مجلة وادي النيل للاراسات و البحوث الإنسانية والاجتماعية والتربوية (مجلة علمية محكمة)}

(ISSN : 2536 - 9555)

textbook materials should be evaluated against certain criteria and in relation to both the textbook's and the learners' objectives, which should be met by the conclusion of the academic year. Alsulami (2021) proposes three distinct types of materials evaluation based on the goal, timing, and formality of their academies: "pre-use evaluation, in-use evaluation, and post-use evaluation." "Pre-use evaluation" entails making judgments about the material's worth to its consumers. It can be contextually irrelevant, contextually influenced, or contextually dependent. This type of evaluation is frequently impressionistic, as it involves a snap judgement by a teacher or an institution, and as a result, certain errors may surface during the book's use. While "while-use evaluation" is more consistent than "pre-use evaluation," it cannot quantify strong or effective learning. "Post-evaluation" is deemed the most critical because it allows for the measurement of the material's effort on the consumers (2010, p.4). As a result, the Ministry of Education should analyze the efficacy of methods for evaluating and assessing English textbooks prior to passing judgment on the objectives attained consistently and excessively.

Additionally, a critical review of the texts should be conducted using experimental methods and small-scale research to gain a better knowledge of what a comprehensive curriculum should entail and whether or not the Ministry Of Education is succeeding in this endeavor.

Arday at el. (2021) examined the components of rational curriculum change, arguing that when the curriculum consists of purposefully and consciously planned activities that are implemented in schools and colleges, the learning outcomes and objectives would almost surely be missed. Language requires a more unconscious sequence of learning, rather than adherence to a deliberately designed curriculum, the latter of which will result in failure to learn. Second, Arday at el. (2021) claimed that the curriculum does not have to accomplish all stated goals. It is not required to meet the defined objectives at the conclusion of the course through specific activities and courses. It becomes evident 


\section{English language learning difficulties in Saudi Arabia: Tabuk University as a case study}

Dr. Nadyh Naser R Alawfi

$$
\text { مجلة وادي النيل للاراسات والبحوث الإنسانية والاجتماعية والتربوية (مجلة علمية محكمة) }
$$

that the primary goal of language instruction should be to supply students with natural and appropriate material that meets their requirements and hence facilitates their acquisition. This strategy may unintentionally assist pupils in acquiring the language, resulting in a satisfactory learning outcome. Thirdly, the essential issue that remains critical in achieving curriculum objectives is defining the objective's premises. For instance, do the objectives take into account a variety of behaviors, skills, concepts, creative powers, and students' abilities to learn and accomplish the specified objectives? Regrettably, Saudi Arabia's curriculum development is highly reliant on the recognition of objectives, which are tested at the conclusion of each term via a written exam. This assessment is used to examine whether the objectives have been met or if more changes should be made. This method ignores the critical impact that other elements may have in the final phases of the learning outcome, as well as the speaking skill assessment. As a result, curriculum development in Saudi Arabia in general, and at Tabuk university in particular, must take into account diverse qualities and situations, rather than being driven by a single overarching educational principle that must be met at the conclusion of the year. Otherwise, without a thorough grasp of the numerous complicated parts that must be combined to provide a satisfactory learning outcome, the teaching curriculum will be a complete waste of time, money, and effort, resulting in unmet teaching and learning objectives and a lack of competency.

Despite the aforementioned arguments and recent curriculum revisions and development, the myth of falling English standards in the Kingdom of Saudi Arabia, and more specifically at Tabuk University, and a lack of emphasis on speaking ability as a result of the courses taught as described above, has not been proven conclusively. There are further significant problems affecting the standard of EFL instruction and speaking proficiency that impede the achievement of the Saudi curriculum's objectives. Along with 


\section{مجلة وادي النيل للاراسات و البحوث الإنسانية والاجتماعية والتربوية (مجلة علمية محكمة)}

(ISSN : 2536 - 9555)

the curriculum, these elements include English teaching tactics, student motivation, anxiety, and reluctance to study English at Tabuk University, all of which can be considered significant factors affecting the standard of learning and teaching practices in Saudi Arabia.

\section{Strategies for Teaching English as a Foreign Language in Saudi Arabia, Tabuk University.}

With regards to Saudi Arabia's curriculum development, it is necessary to provide a description of Tabuk University's ongoing English language course, particularly in the foundation year, in order to conduct a theoretical analysis of various aspects of language teaching and the distinctive features of Tabuk University's English language classes. These factors and characteristics include the motivation of students, teacher-student interaction, language focus, and the general ambiance of language classes.

As a required component of completing the foundation year, Tabuk University provides English language classes based on its "Intensive English Language Programs," which utilize the "Cambridge Touchstone" as the program's primary text. The purpose of these classes is to enhance students' English language proficiency and to assist them in attaining the desired level of proficiency within the contexts of the majors they will pursue following their foundation year. The grade students earn in this English language course will indicate their level of ability in English and will determine which majors they are eligible to pursue.

According to the data collection and observations of ten courses, the number of enrolled students in each language class may be as high as 30, affecting student-teacher interaction. However, according to the teacher's statistics, the average number of pupils who attend lessons consistently is between 12 and 25. I attended English language classes at Tabuk university's "foundation year" 


\section{English language learning difficulties in Saudi Arabia: Tabuk University as a case study}

Dr. Nadyh Naser R Alawfi

$$
\text { مجلة وادي النيل للاراسات والبحوث الإنسانية والاجتماعية والتريوية (مجلة علمية محكمة) }
$$

level during the data collection period for this research in order to learn more about the factors that affect students' English language ability, particularly in terms of speaking. Each language class's enrollment continued to decline throughout the year, as more students dropped out to study for midterm or final exams. Furthermore, absenteeism and declining attendance are ingrained habits not only among Tabuk University students, but also at Saudi universities and colleges more broadly. Alghonaim (2021) has explored Saudi students' opinions about English language education at Saudi universities and colleges, relating them to a variety of environmental and social issues.

Text anxiety/tension may have a connection with the curriculum. Additionally, there may be learning difficulties associated with coping with the offered text, fear of failure, a lack of motivation (all of which will be described in greater detail later in this paper), peer pressure, and a negative attitude toward the academic institution. Additionally, there is the forced option problem, in which students are required to attend an entire day of English instruction at Tabuk University. This attendance policy of prohibiting students from leaving campus was amended in 2011, when the course was expanded to a full nine-hour day, from 8 a.m. to 5 p.m. on working days. After the first class, students are unable to miss or cancel classes for the remainder of the day; they are required to remain on the university campus for the duration of the day, which results in a considerable decline in attendance. This is a result of the university's new policy regarding foundation-year students, who are no longer permitted to leave campus during working hours due to a variety of cultural concerns. Soltanian, Ghapanchi, \& Pishghadam (2020) addressed the effect of emotional or social problems on students' performance and achievement in language acquisition, demonstrating that students fared better when their attitudes toward language learning were positive and strong. Khan (2007, p. 1) identified the following 


\section{مجلة وادي النيل للاراسات والبحوث الإنسانية والاجتماعية والتربوية (مجلة علمية محكمة)}

(ISSN : 2536 - 9555)

variables as barriers to learning in the Saudi context: "The barriers include a variety of very influential aspects, including social, cultural, parental, attitudinal, motivational, psychological, personal, and educational ones. Pedagogical influences include, but are not limited to, teachers, action research, instructional strategies, instructional resources, and administration "'. The existence of such significant characteristics can be striking and can exacerbate pupils' potential for language learning, not only in speaking, but in all skills. According to Stoos \& Haftel (2020), such elements become ingrained in students' attitudes toward learning, and language practitioners should engage with other consultation departments within the academic institution to resolve such issues.

\section{Student Motivation Towards Language Learning}

One probable explanation for students' lack of motivation to attend English language sessions at Tabuk University, and according to the data collected for this study, is that they are required to attend five hours of English classes daily for a full year with the same teacher in the same room. They are supposed to concentrate on only two abilities during this time period: reading and writing, while nearly completely abandoning speaking and listening exercise. Additionally, because students are evaluated through a written exam at the end of the semester and are not required to use the second language outside of the classroom, they are unable to develop the level of competency necessary to speak in English utilizing the four basic language skills. Additionally, students use the language within the classroom to address a specific aspect of the curriculum. Regrettably, the language learning method in this situation violates the Ministry's declared goals for the English language curriculum. Azim at el. (2020) emphasized the importance of motivation in language learning. This could be a result of pupils' lack of enthusiasm for the English education. Miller at el.1, on the other hand, defined motivation as "the product of effort and the desire to accomplish a language learning goal, as well as attitudes or the degree of interaction orientation" (2019, p. 168). Additionally, motivation is defined as "a collection of 


\section{English language learning difficulties in Saudi Arabia: Tabuk University as a case study}

Dr. Nadyh Naser R Alawfi

مجلة وادي النيل للاراسات والبحوث الإنسانية والاجتماعية والتربوية (مجلة علمية محكمة)

numerous distinct and overlapping reasons such as interest, curiosity, or a drive to achieve" (Kim, 2020, p.518). As a result, highly driven students seek opportunities to practice their second language and are more successful in developing oral communication skills than less motivated students (Soltanian, Ghapanchi, \& Pishghadam, 2020). Saudi English classes are limited to students from Saudi Arabia whose first language is Arabic. Within the classroom, these children primarily speak Arabic and do not communicate with their teacher, who is an English native speaker. This aspect will be examined in further length in the future, particularly in relation to teacher attitudes toward teaching English at Tabuk University.

According to Azim at el. (2020), there are two types of motivation for students to learn the English language: I the desire to use language as a tool to accomplish a specific goal, or (ii) the desire to engage in specific activities, such as joining another group in a different culture, which is not applicable in the Saudi context. Both of these criteria may be beneficial in assessing student attitudes toward language acquisition, particularly the issue of classroom speaking skills. Outside of the classroom context, students have a limited opportunity to practice their second language. Additionally, Goh, C. C., \& Vandergrift (2021) classified learner needs into two broad categories. The term "objective needs" refers to the teacher's efforts that involve diagnosing the student's aptitude and language competence and utilizing the student's own knowledge by giving the appropriate degree of language teaching. The other type of necessity is subjective. This includes the student's aspirations, objectives, and expectations. This examination is carried out through a planning process.

The teacher proposes the program with the assistance of the academic organization. Regrettably, insufficient focus is given on significant impediments such as these, which contribute to Tabuk 
مجلة وادي النيل للار اسات والبحوث الإسانية والاجتماعية والتربوية (مجلة علمية محكمة)

(ISSN : 2536 - 9555)

University's supply of an improper learning environment. Alternatively, because language acquisition requires participation in a language learning setting, the student's mindset, as well as the teacher, classroom, textbooks, and learning environment, all play a critical influence. Dörnyei (2020). discovered that linguistic attitudes were the best predictors of English learning achievement in schools and colleges, whereas Zólyomi (2021) discovered that motivation plays a significant role in achievement, even among military people. Similarly, Modarresi \& Javan (2018) discovered that those who dropped out of language classes demonstrated decreased language proficiency, significantly lower aptitude ratings, and fewer favorable attitudes regarding the language learning environment.

Another significant motivator associated with a positive attitude toward language learning is what is referred to as the "foreign language-learning setting." According to Schiller \& Dorner (2021), when students learn a foreign language at school without direct interaction with native speakers, it has a detrimental influence on their willingness to communicate and results in decreased oral communication. As a result, students may be discouraged from using their English language abilities outside of the classroom. For instance, as part of the data collection process for determining the English language learning obstacles, one of the English classes offered at Tabuk University during my foundation year was a speaking class covering the "Money Unit" as part of the curriculum, based on the Touchstone course book. The lesson's primary objective was to teach students how to apply rules to a variety of various forms of content. Unfortunately, the teacher relied heavily on reading from the book rather than engaging students in conversations, despite the fact that this is the most effective technique for concluding the unit in the textbook in accordance with the department's requirement. This may have contributed to students' discontent with the quality of English language instruction, which has an effect on their attitudes about language. Rogers (1983), a humanistic language psychologist, 
English language learning difficulties in Saudi Arabia: Tabuk University as a case study

Dr. Nadyh Naser R Alawfi

مجلة وادي النيل للاراسات والبحوث الإنسانية والاجتماعية والتربوية (مجلة علمية محكمة)

emphasizes the importance of dealing with the "'whole learner" and emphasized that "learners are not merely information processors who leave the deeper layers of their identity outside the classroom; they are real people who bring the full range of personal attributes and feelings with them." These must be respected if personal development and growth are to occur "'. (Muhamadjonovna, 2020, p.98).

Additionally, Chandra, \& Kerlin (2021) research established a relationship between motivation and second language competency. This author stated that motivation is critical for language learning and is directly related to students' language acquisition competence. Reynolds also distinguishes between several types of motivation. The first, which refers to the effort required to learn a second language, is referred to as motivational intensity. The second type of motivation relates to the individual's motivation for studying the language. As a result, classroom performance is linked to students' ambition to learn a foreign language and their ability to engage effectively in a second language classroom, which appears to be lacking in the case of Saudi students studying English at Tabuk University.

\section{Anxiety}

Throughout my data collecting at Tabuk University and in the foundation year classes, and as a result of the several elements I discovered that work against students acquiring language competency, particularly their communication abilities in a speaking class, is worry. Indeed, numerous studies have been conducted on the association between anxiety and second language acquisition. For example, Lee \& Drajati (2019) demonstrated that foreign language anxiety is distinct from other types of anxiety and that there is a correlation between anxiety and proficiency in learning. This, they contended, is related to students' attitudes toward language acquisition and is specifically associated with 
مجلة وادي النيل للاراسات والبحوث الإنسانية والاجتماعية والتربوية (مجلة علمية محكمة)

(ISSN : 2536 - 9555)

speaking and listening. Anxiety is a "subjective sensation of tension, apprehension, uneasiness, and worry" (Mamajonova, 2021). Additionally, Jin, Zhang, \& MacIntyre (2020) characterized anxiety in the context of language learning as "a specific complex of self-perception, beliefs, feelings, and behaviors associated with classroom language learning that arises from the process's distinctiveness." Additionally, he characterized the relationship between anxiety and speaking specifically as "a consistent psychological feature pertaining to an individual's proclivity to respond nervously when speaking in a second language." Additionally, Jin, Zhang, \& MacIntyre (2020) and Mamajonova (2021) stated that fear can serve as a powerful motivator for pupils. It can either stimulate kids to learn a language or have a detrimental effect, stopping them from completing the learning process and hence possibly preventing them from reaching effective oral communication. Zhang's study establishes that students were fearful of oral communication as a result of their language acquisition challenges. They lacked sufficient mastery of the second language, which increased their anxiety about practicing the language in the classroom. Their lack of real-world communication experience caused them to be concerned about their speech production, which resulted in speaking difficulties and low self-esteem. According to Mamajonova (2021), one of the most significant elements that operate as a barrier to language learning in English classes in the Saudi setting is learners' worry about the learning environment. However, Saudi students confront linguistic barriers at the tertiary level of study when it comes to English language proficiency. Ahmad Al-Khotaba at el. asserts "Due to the fact that English is the medium of teaching and the target learners appear to come from humble origins, they are frequently fearful of learning a subject in English in general and studying English in particular. They occasionally make an attempt to learn, but English looks to be one of those barriers that they are even frightened to confront " (2020, p. 123). Additionally, one of the essential features of efficient language instruction at Tabuk University was discovered to be lacking in the English classrooms. 


\section{English language learning difficulties in Saudi Arabia: Tabuk University as a case study}

Dr. Nadyh Naser R Alawfi

$$
\text { مجلة وادي النيل للاراسات والبحوث الإنسانية والاجتماعية والتريوية (مجلة علمية محكمة) }
$$

How can we expect learners whose primary objective is to pass an examination based on a prescribed curriculum (without having a say in what they study) to pick up the language? In the majority of studies, it is discovered that interactive motivation between the learner and the learning environment results in the best learning outcome. The simplest and most evident characteristic that draws individuals to language acquisition is their involvement in activities that engage their thoughts with the language through the use of creative resources in a variety of circumstances. As a result, they are able to speak in this language. Learners at the university level are distinct from students at the high school level; the latter require their own learning environment in order to generate a positive learning income. They must discuss the usefulness of the natural language class in which they work with the teacher. Muhamadjonovna, noted that "creating space for learners" meant that "each individual learner should not feel endangered by factors beyond his or her control (e.g., a hostile audience) or that his or her social identity should be buried anonymously within the class (2020, p. 99).

Although some study established a clear link between personal features and sentiments in language acquisition, the findings indicate that personal emotions, such as anxiety, are a significant component in the acquisition of conversational and oral communication skills (Lightbown \& Spade, 1999).

While it is true that some learners' attitudes toward learning a second language, including motivation and anxiety, are critical to their success in interactive communication in general and speaking skills in particular, the strategies for teaching English at Tabuk University must take these factors into account.

\section{Reluctance of Students}

According to the data gathered for this study, pupils prefer to remain silent during English language sessions. They did not 


\section{مجلة وادي النيل للاراسات و البحوث الإنسانية والاجتماعية والتربوية (مجلة علمية محكمة)}

(ISSN : 2536 - 9555)

appear to be capable of speech communication. This is referred to as "student reticence," and it refers to a student's reluctance to communicate. According to Peng (2020), the cause for student reluctance is extremely complex. Numerous elements influence student personality, which are interconnected with other areas such as personal attitude, confidence, motivation, and anxiety. These entwined elements have an effect on students' classroom behavior, which results in their lack of oral communication abilities. Additionally, Kim (2020) claimed that students' behavior in a second language classroom is complicated and interdependent on a variety of factors, including motivation, anxiety, and personal attitude toward the language, all of which can contribute to student reluctance.

Additionally, Miskam \& Saidalvi (2020) established a relationship between oral production and a variety of personal attitudes, including anxiety and motivation. The scenario that second language learners (particularly those taking language programs at Tabuk University) find themselves in when speaking is not easy. Students' lack of knowledge and confidence can create a variety of challenges, including the desire for certain students to remain mute and interact ineffectively as a result of their lack of selfconfidence. Such behavior may be a significant role in student reluctance. Additionally, Pinner (2019) 1claimed that the majority of students studying the English language initially feel very driven and nervous. He emphasized that when students arrive at class and are engaged in speaking activities, they begin the process of speech creation. This is when kids become aware of their speaking challenges, and as a result, they may develop unfavorable attitudes toward the foreign language and may prefer to remain silent rather than engage in speaking activities owing to a lack of confidence. Hundreds of research, on the other hand, have been done to ascertain the relationship between student behavior and the language acquisition process. According to Azim at el. (2020), the majority of research on second language acquisition and oral communication competence is mostly dependent on students' 


\section{English language learning difficulties in Saudi Arabia: Tabuk University as a case study}

Dr. Nadyh Naser R Alawfi

$$
\text { مجلة وادي النيل للاراسات والبحوث الإنسانية والاجتماعية والتربوية (مجلة علمية محكمة) }
$$

individual traits. These are the variables that influence learning and motivation, as well as learners' anxiety and self-confidence. Students who lack particular qualities may struggle with learning and have reduced speech production. To assist students in improving their ability to communicate in the classroom, teachers must be aware of both the teaching situation, such as why learners are learning the language, and of individual students who may be influenced by a variety of factors, such as motivation, anxiety, and willingness to speak. Due to the administration's and English language course directors' lack of understanding at Tabuk University, it appears that a greater emphasis should be placed on these elements. Additionally, they should be aware that continuing to employ old teaching methods and particular textbooks that emphasize written forms while ignoring the importance of oral communication within the English language classroom will result in insufficient language development. Additionally, Soltanian, Ghapanchi, \& Pishghadam (2020) highlighted several strategies for treating human qualities (such as fear and motivation) related with oral skills in a language learning scenario, as well as how to generate opportunities for the learner to practice.

They should practice the target language according to their requirements. Newton, \& Nation, (2020), Lechtenberg, 2021, Swan (2018), and Miskam \& Saidalvi (2020) proposed various methods and activities that could assist students in becoming more motivated, less worried, and more optimistic about learning, so assisting them in overcoming the aforementioned difficulties. The primary point of agreement among these authors is the importance of stimulating students' desire to speak the language and including them in as many activities as possible. According to Newton, \& Nation, (2020), teachers should encourage students to interact effectively and offer them the opportunity to speak. Additionally, Mamajonova (2021) report that highly driven students value communicative classes and favor those that balance the teacher's 


\section{مجلة وادي النيل للاراسات والبحوث الإنسانية والاجتماعية والتربوية (مجلة علمية محكمة)}

(ISSN : 2536 - 9555)

role with learner-centeredness. As a result, Newton, \& Nation, (2020) proposed that teachers devote a brief amount of time to individual students at the start of the speaking activity and then organize the activities in pairs, trios, and small groups before incorporating the full class, including the teacher, in the discussion. Students who are less motivated may view this as an advantageous opportunity to participate, as they will be speaking to the entire class, including the teacher. Additionally, Miskam \& Saidalvi (2020) suggested that teachers may place a greater emphasis on students' attitudes than on the techniques employed in the speaking class, which teachers may profit from in the instance of Tabuk University's language center. He thinks that "success (in language) is less on resources, methodologies, and linguistic analyses and more dependent on what occurs within and between the classroom's participants" (Miskam \& Saidalvi, 2020). In other words, the instructor should foster a pleasant learning environment for students by encouraging participation and including them in speaking activities that help them enhance their communication skills. Additionally, I believe that students enrolled in Tabuk University's language classes should ascertain what motivates them to engage in oral communication. Additionally, it would be beneficial if the language teacher examines the strengths and weaknesses of their students' language abilities, bases their judgment on the students' needs, and incorporates the students' experience with English language communication. At the moment, the university educational system and the Ministry of Education's curriculum make it difficult for both students and teachers to learn in an unstructured setting devoid of textbooks. According to Newton, \& Nation, (2020), teachers should attempt to assign a topic that is directly relevant to the students' personal difficulties rather than relying on the textbooks provided. Thus, even the less chatty students may regard it as an opportunity to discuss their own interests and feelings, thereby increasing their motivation to interact. 
English language learning difficulties in Saudi Arabia: Tabuk University as a case study

Dr. Nadyh Naser R Alawfi

مجلة وادي النيل للاراسات والبحوث الإنسانية والاجتماعية والتربوية (مجلة علمية محكمة)

Finally, because anxiousness is a challenging issue in this setting, Jin, Zhang, \& MacIntyre (2020) proposed that teachers encourage students to express their sentiments and interests in their free time or at the start of class. Additionally, Saudi students at Tabuk University should have time for private consultations with their teachers to see if there are any issues with language learning, class, or school, and the English language course director should take the aforementioned factors into account. As a result, students may develop a more favorable attitude toward the second language and become more driven to practice and study the language both within and outside the classroom.

\section{Conclusion and Observations}

My studies and participation in English classes at Tabuk University indicate that Saudi Arabia's educational system for teaching second languages may be improved. The most critical life skills are speaking and listening, but the Ministry of Education has not developed a course for pupils that emphasizes the necessity of verbal communication. Rather than that, course books emphasize reading and writing, resulting in a slew of difficulties, most notably fear and reluctance when called upon to practice speaking. Additionally, student motivation has been harmed by the Ministry of Education's restrictive English curriculum: during their foundation year of university, students must spend numerous hours each day in a classroom with the same teacher, attempting to complete the strict textbook. Neither professors nor students are permitted to depart from the course, which results in a significant loss of motivation for both. Teachers are unable to introduce topics that are more relevant to their students' personal situations, and studying English becomes a race to finish the textbook in time for the end-of-year tests. Speaking is not emphasized at all; in fact, assessments are entirely written, and students are discouraged from conversing in English both inside and outside the classroom. The Ministry of Education and Tabuk University's Higher 


\section{مجلة وادي النيل للاراسات والبحوث الإسانية والاجتماعية والتريوية (مجلة علمية محكمة)}

(ISSN : 2536 - 9555)

Administration, as well as academic instructors and language teachers throughout Saudi Arabia, should be aware of these critical issues and learning barriers in English teaching, and a process of language learning should be developed that provides opportunities for students to improve their communicative abilities while also allowing teachers to have input into their students' learning programs.

\section{References}

- Ahmad Al-Khotaba, H. H., Alkhataba, E. H. A., AbdulHamid, S., \& Ibrahim, B. (2020). Foreign language speaking anxiety: A psycholinguistic barrier affecting speaking achievement of Saudi EFL learners. Arab World English Journal (AWEJ) Volume, 10.

- $\quad$ Al Haq, A. F. (2020). Spoken English Skills and Saudi EFL Undergraduates: A Case Study. The Asian ESP Journal, 57.

- Alakrash, H. (2021). Factors Affecting the Application of Communicative Language Teaching CLT in Syrian Schools. TESOL and Technology Studies, 2(1), 1-14.

- Alghonaim, A. S. (2021). Intrinsic Motivation and Speech Production in Saudi EFL College Students. Journal of Psycholinguistic Research, 50 (5), 1137-1157.

- Alhajailan, D. (2020). A syntactic analysis of Arabic language interference in the written English of Saudi female college students (Doctoral dissertation, University of Roehampton).

- AlHarbi, A. A. (2021). EFL teacher preparation programs in Saudi Arabia: An evaluation comparing status with TESOL standards. Pegem Journal of Education and Instruction, 11(4), 237-248.

- Alqahtani, S. M. A. (2018). Teaching English in Saudi Arabia. In English as a Foreign Language in Saudi Arabia 
English language learning difficulties in Saudi Arabia: Tabuk University as a case study

Dr. Nadyh Naser R Alawfi

مجلة وادي النيل للاراسات والبحوث الإنسانية والاجتماعية والتربوية (مجلة علمية محكمة)

(pp. 120-137). Routledge.

- $\quad$ Alshammari, S. R. (2020). " Writing to Learn or Learning to Write". A Critical Review of" English as a Foreign Language"(EFL) Teaching Practices in Writing in Saudi Universities.

- Alsuelmi, A. (2021). Perceptions of faculty members on the value of distance education at two different types of institutions of higher education in The Kingdom of Saudi Arabia (Doctoral dissertation).

- Alsulami, Y. A. K. (2021). An Evaluation of a Fourth Level English Textbook Used in Secondary Schools in Riyadh City. English Language Teaching, 14(2), 68-83.

- Arday, J., Zoe Belluigi, D., \& Thomas, D. (2021). Attempting to break the chain: Reimaging inclusive pedagogy and decolonising the curriculum within the academy. Educational Philosophy and Theory, 53(3), 298313.

- Arday, J., Zoe Belluigi, D., \& Thomas, D. (2021). Attempting to break the chain: Reimaging inclusive pedagogy and decolonising the curriculum within the academy. Educational Philosophy and Theory, 53(3), 298313.

- $\quad$ Azim, M. U., Hussain, Z., Bhatti, A. M., \& Iqbal, M. (2020). Recycling of vocabulary in English Language Teaching: From theory to practice. Epistemology, 7(1), 88-102.

- $\quad$ Azim, M. U., Hussain, Z., Bhatti, A. M., \& Iqbal, M. (2020). Recycling of vocabulary in English Language Teaching: From theory to practice. Epistemology, 7(1), 88-102.

- Barashid, M. (2020). Analyzing the Content of Reading Texts Questions in Flying High for Saudi 
مجلة وادي النيل للاراسات والبحوث الإنسانية والاجتماعية والتربوية (مجلة علمية محكمة)

(ISSN : 2536 - 9555)

Arabia. International Education Studies, 13(6), 96-103.

- Chandra, Y., \& Kerlin, J. A. (2021). Social entrepreneurship in context: pathways for new contributions in the field.

- Dörnyei, Z. (2020). Innovations and challenges in language learning motivation. Routledge.

- $\quad$ Getie, A. S. (2020). Factors affecting the attitudes of students towards learning English as a foreign language. Cogent Education, 7(1), 1738184.

- $\quad$ Goh, C. C., \& Vandergrift, L. (2021). Teaching and learning second language listening: Metacognition in action. Routledge.

- $\quad$ Jin, Y., Zhang, L. J., \& MacIntyre, P. D. (2020). Contracting students for the reduction of foreign language classroom anxiety: an approach nurturing positive mindsets and behaviors. Frontiers in Psychology, 11, 1471.

- Lechtenberg, K. (2021). Beyond good intentions: A critical discourse analysis of teaching tolerance's 'teaching the new jim crow: A teacher's guide'. Journal of Curriculum Studies, 53(1), 83-102.

- $\quad$ Lee, J. S., \& Drajati, N. A. (2019). Affective variables and informal digital learning of English: Keys to willingness to communicate in a second language. Australasian Journal of Educational Technology, 35(5), 168-182.

- Mamajonova, M. N. K. (2021). THE IMPORTANCE OF INSTRUMENTAL AND INTEGRATIVE MOTIVATION IN SECOND LANGUAGE ACQUISITION. Academic research in educational sciences, 2(3).

- Miller, C. L., Manderfeld, M., \& Harsma, E. A. (2019). Learning Theories: Multiple Intelligences.

- Ministry of Education, Saudi Arabia (2010). English for Saudi Arabia: 3rd Year Secondary Term 2.Riyadh: Ministry of Education. 
English language learning difficulties in Saudi Arabia: Tabuk University as a case study

Dr. Nadyh Naser R Alawfi

مجلة وادي النيل للاراسات والبحوث الإنسانية والاجتماعية والتربوية (مجلة علمية محكمة)

- Ministry of Education, Saudi Arabia (2012). Challenge:

English language Student Book, Level Five. Riyadh: Ministry of Education.

- Ministry of Higher Education (2013) Progress of Higher Education in The Kingdom of Saudi. (Riyadh, Ministry of Higher Education).

- Miskam, N. N., \& Saidalvi, A. (2020). Using Video Technology to Improve Oral Presentation Skills among Undergraduate Students: A Systematic Literature Review. International Journal of Psychosocial Rehabilitation, 24(05).

- Modarresi, G., \& Javan, E. (2018). Construction and Validation of Foreign Language Learners' Dropout Questionnaire. International Journal of Instruction, 11(4), 425-444.

- Muhamadjonovna, S. D. (2020). A Set Of Methodological Tools For The Formation Of Sociolinguistic Competence Of Future English Teachers. The American Journal of Social Science and Education Innovations, 2(12), 298-302.

- $\quad$ Newton, J. M., \& Nation, I. S. P. (2020). Teaching ESL/EFL listening and speaking. Routledge.

- $\quad$ Peng, J. E. (2020). Teacher interaction strategies and situated willingness to communicate. ELT Journal, 74(3), 307-317.

- Pinner, R. (2019). Authenticity and teacher-student motivational synergy: A narrative of language teaching. Routledge.

- Saleh Alharbi, A., Abdullah Alhebshi, A., \& Meccawy, Z. (2021). EFL Students' and Teachers' Perceptions of Google Forms as a Digital Formative Assessment Tool in Saudi Secondary Schools. Arab World English Journal (AWEJ) 
مجلة وادي النيل للاراسات والبحوث الإنسانية والاجتماعية والتريوية (مجلة علمية محكمة)

(ISSN : 2536 - 9555)

Special Issue on CALL, (7).

- $\quad$ Schiller, E., \& Dorner, H. (2021). Factors influencing senior learners' language learning motivation. A Hungarian perspective. Journal of Adult Learning, Knowledge and Innovation.

- Soltanian, N., Ghapanchi, Z., \& Pishghadam, R. (2020). Language Learners' Imagined Communities: Model and Questionnaire Development in the Iranian Context. Applied Research on English Language, 9(2), 155-182.

- Stoos, K. B., \& Haftel, M. (2020). Rethinking the use of undergraduate teaching assistants through multiple modes of communication outside of the classroom. International Journal of Arts \& Sciences, 13(1), 95-103.

- Swan, M. (2018). The Practice of English Language Teaching.

- $\quad$ Troudi, S., \& Hafidh, G. (2017). The dilemma of English and its roles in the United Arab Emirates and the Gulf. Gulf Research Center.

- Welcome to Research at Tabuk University (2006). Retrieved from https://www.ut.edu.sa/en/Deanship/scientificresearch/Pages/default.aspx

- Zhang, L. (2001). Exploring Variability in Language Anxiety: Two Groups of Pre Students Learning Esl in Singapore. RELC Journal, 32(1): 73 - 91.

- Zólyomi, A. (2021). Investigating language aptitude in the success of adult second language acquisition. Journal of Adult Learning, Knowledge and Innovation. 